Religion and Gender, vol. 2, no. 2 (2012), pp. 231-253

www.religionandgender.org

URN:NBN:NL:UI:10-1-101602

ISSN: $1878-5417$

Publisher: Igitur Publishing (Utrecht)

Copyright: this work is licensed under a Creative

Commons Attribution License (3.0)

\title{
Reforming Men, Refining Umma: Tablīghī Jamā'at and Novel Visions of Islamic Masculinity
}

\author{
HALKANO ABDI WARIO
}

\begin{abstract}
Tablīghī Jamā'at, a pietistic movement run by laypeople that originated in India is currently the most widespread Muslim missionary group worldwide. It is essentially men-oriented in terms of its main target for proselytization and organization. Spaces of proselytization are mosques, sacred spaces frequented by men, and the home, a place of reinforcement of 'lifestyle evangelism' dominated by women. The group has been described as anti-intellectualist, apolitical, docile, otherworldly, and a front for militant groups. Based on recent ethnographic research in northern Kenya, the paper explores two main thematic questions: What does it take to be a Tablīghī man? Does emerging Tablīghī masculinity embolden or reconfigure gender/patriarchal relations? The paper posits that the movement provides social mobility for non-'ulamā men in an alternative religious hierarchy but also lays the foundation for the emergence of a transnational practice of Islamic masculinity that appropriates the different local versions of being and becoming a man.
\end{abstract}

\section{Keywords}

Tablīghī masculinity, non-'ulamā men, gender, jamā’at 


\section{Author affiliation}

Halkano Abdi Wario recently finished his doctoral studies at Bayreuth International Graduate School for African Studies at Universität Bayreuth, Germany. Email: halkanoabdi@gmail.com

\section{Introduction}

'It is tough being a Tablīghī man,' argued one informant in Kenya. The reason: he spends about 40 days to four months almost every year from home; travels in rough terrains sometimes on foot with limited food and water; sleeps on hard floors in different parts of the country while on preaching tour; learns to cook and wash utensils while on tour; is expected to shun politics, controversies, violence, idle talks and other forms of activism, and be an embodiment of a 'proper' Muslim. 'The days of dictatorship are over,' said Rashid. 'Now more than ever we have to consult our wives, build trust and on personal level I have learnt my responsibilities and duties as a father and a husband. ${ }^{1}$ Rashid and two other secondary school teachers in Moyale (a town on the Kenya-Ethiopian border) were discussing with me how their membership in the Tablīghi Jamā'at has impacted on their everyday life. They represent the new face of religious change. They are secular, educated, employed, and at the same time engaged in lay preaching and organizational activities of the local Tablīghi unit during their free time. Rashid and his friends were referring to myriads of religious practices and travel modules that involve participation of men and women for their success. This includes consultative meetings at home (shūrā fil bayt), spousal proselytism tours (masturat jamā'at), and home-based instructional sessions (ta'lim fil bayt). These men, themselves members of their local mosque-based units, are the transformative link between the local and the translocal in bringing the Tablīghi version of religious reform home. Mainly men travel and gather for regular Tablīghī congregations.

\section{Conceptualizing Masculinity}

Using the wording of Lahoucine Ouzgane, this article

adopts a social constructionist perspective and is premised on the belief that men are not born; they are made; they construct their masculinities within particular social and historical contexts. Thus, masculinities in Islamic

1 Group discussions with Rashid, Abdu, and Abdi Bashir, Moyale: June 2010. 
contexts emerge as a set of distinctive practices defined by men's positionings within a variety of religious and social structures. ${ }^{2}$

Much of current literature about masculinity starts from the standpoint of rejection that all men are the same and that they have the same amount and type of power, or the same opportunities and life trajectories. ${ }^{3}$ Masculinity, therefore, is viewed as not an essential quality but a fluid and fragile identity resource that is socially constructed through everyday social interactions. Different modes of masculinity are evaluated hierarchically and most often against hegemonic masculinity, the dominant ideal of masculinity of how a man 'ought' to be and behave to be accepted as masculine. ${ }^{4}$

Quoting R. Morrell, Carolyn Elliot states that hegemonic masculinity not only presents a vision of how 'real' men should behave and is oppressive to women, but it also tends to silence other masculinities, placing them in opposition to itself and depriving them of currency and legitimacy. Within religious communities, competing versions of masculinities exist. ${ }^{5}$ The dominant tradition defines the borders of the ideal and guards against alternatives that appear to upset limits of hegemonic masculinity. Are the Tablīghi 'acting like female'? ${ }^{6}$ Why are they often depicted as non-confrontational and aloof from political and social activism, which are defining characteristics of many religious movements in the Muslim world? The paper will also explore the theme of othering Tablighi masculinity through polemical discourses that disqualify the men's religious practices as neglectful of the masculine duties husbands and fathers should fulfil and accuse them of 'meekness' and other-worldliness due to their rejection of political activism.

Religious communities worldwide have set standards for gender relations and for behaviour required of men, women, and children. Such

2 L. Ouzgane (ed.), Islamic Masculinities, London: Zed Books 2006, 2

3 See also L. Ouzgane and R. Morrell, African Masculinities: Men in Africa from the Late Nineteenth Century, New York: Palgrave Macmillan 2005.

4 K. Talbot and M. Quayle, 'The Perils of Being a Nice Guy: Contextual Variation in Five Young Women's Constructions of Acceptable Hegemonic and Alternative Masculinities', Men and Masculinities 13:2 (2010), 255-278.

5 See C. Elliott, Global Empowerment of Women: Responses to Globalization and Politicized Religions, London: Routledge 2007 and R. Morrell, 'Of Boys and Men: Masculinity and Gender in Southern African Studies', Journal of Southern African Studies 24:4 (1998), 605-30.

6 B.D. Metcalf, 'Tablīghī Jamā'at and Women' in M.K. Masud (ed.), Travellers in Faith: Studies of the Tablïghi Jamā'at as a Transnational Islamic Movement for Faith Renewal, Leiden: Brill 2000, 45. 
views of masculinity and femininity have been debated and modified over the years by religious scholars ('ulamā) and laypeople alike. Etin Anwar rightly observes that the engendering process of masculinity and femininity in the context of a Muslim life is a lifetime project and is promulgated by Muslim legal scholars, preachers, and mystics through religious media, religious meetings, literature, and speeches. ${ }^{7}$ Interpretation of the Quran, Sunnah (actions and deeds of Prophet Muhammad), fiqh (jurisprudence), local understanding of the Islamic faith, and indigenous norms and customs form the basis for seeking legitimacy and authority in discussions about gender relations. To preach to mosque attendants is one such outlet for influencing the behaviour of fellow believers. In an ordinary setting not every man gets an equal chance to preach, interpret religious texts, and guide the confessional Muslim community. This supposition, however, forms the central thesis of Tablīghi ideology: every man is seen by definition as a preacher who should tell other believers to be steadfast in their religious obligations.

R.W. Connell and J. Messerschmidt observe that research on hegemonic masculinity needs to give close attention to the practices of women and to the historical interplay between femininities and masculinities, to incorporate a more holistic understanding of gender hierarchy, recognize the agency of subordinated groups as much as the power of dominant groups, and examine conditioning between gender and other social dynamics. ${ }^{8}$ By citing case studies, this paper highlights gender dynamics in the formulation of Tablīghi masculinity vis-à-vis competing notion of masculinities. In northern Kenya, pre-existing Borana and mainstream Islamic masculinities impact on and configure what it means to be a Tablīghī man. In turn, the resultant Tablīghī masculinity incorporates an ambivalent understanding of women's status that wavers between women's empowerment and reinforcement of patriarchal control.

\section{Note on Methodology and Data}

The data used in the paper are sourced primarily from fieldwork done in Kenya in April 2009, from August to October 2009, and from April to August $2010 .{ }^{9}$ Ethnographic data were collected through attendance of

7 See E. Anwar, Gender and Self in Islam, London: Routledge 2006.

8 R.W. Connell and J.W. Messerschmidt, 'Hegemonic Masculinity: Rethinking the Concept', Gender \& Society 19:6 (2005), 829-859.

9 The ages of the interview partners ranged from 18 to 78 years and they mainly belonged to Borana-speaking communities of northern Kenya such as Borana, Garre, Sakuye, Burji and Gabra. Interviews were conducted in Swahili, Borana and English. 
transnational Tablīghī gatherings in Nairobi, Isiolo, and Moyale and through formal and informal interviews with members of the Tablīghĩ Jamāat (TJ) and religious leaders drawn from mainstream salafi and Sufi traditions. ${ }^{10}$ Observations and field notes from travel experiences with Tablighīs at preaching tours enriched the research and enhanced the understanding of reversal of gender roles and reformulation of how to be 'an ideal Muslim man' as envisioned in the Tablīghi ideology. ${ }^{11}$

Of Kenya's 40 million people, slightly more than 11 per cent are Muslims. ${ }^{12}$ Kenyan Muslims are a diverse group with varying doctrinal and

While some of the older interviewees lacked formal educational training, a large number of them had basic to university education. While most of the informants are either self-employed or unemployed, several of them worked as teachers, medical personnel, soldiers and non-governmental organization employees. Most of the interviews and participant observations were conducted in northern Kenyan urban centres such as Merti, Moyale, Isiolo, Kinna and Sololo and also at Tablīghi bi-annual gatherings in Nairobi. Being a local Borana Muslim though not a Tablīghī myself, to me the study provided insightful balance of etic and emic perspectives that strengthened the ethnographic research.

10 Sufism (tasawwuf) refers to the mystical expressions of Islam, wherein experiential knowledge of God and attainment of unity in or with him are primary goals. Sufis organize themselves into groups called tariqa (path). Salafism refers to a cluster of different Sunni renewal and reform movements and ideologies in contemporary Islam. The term is based on the Arabic word salaf al-salih (the righteous ancestors). Followers of Salafism consider these ancestors to be the Muslims who had lived during early centuries of Islam, especially the Companions of the Prophet Muhammad (until 712), their Successors (the tabiin) in the second generation (until 796), and then the Successors of the Successors in the third (until 855). Cf. J.E. Campo, Encyclopedia of Islam, New York: Facts on File 2009, xxvi, 601. In northern Kenya, three brotherhoods had large following until the 1980s, namely the Sheikh Hussein tariqa, the Qadiriya, and the Salihiya. The most widespread Salafist ideology in Kenya is that of Wahabism. It was an anti-Sufi reformism started by Muhammad Abdul Wahab. The ideology is often accused of literalist interpretation of Islam. The Saudi regime is associated with promotion and spread of this reformist trend in different parts of the world.

11 In total, 35 face-to-face interviews were conducted in the period stated above of which about seven were focused group interviews. The respondents included novices, regular Tablīghīs, Tablīghī leaders, and local and national non-Tablīghī religious leaders. Ethnographic research that relied mainly on participant observation was done at five national gatherings of Tablīghīs in different parts of Kenya as well as during a ten-day travel with the missionary group. Most interviews were conducted in Swahili and Borana, transcribed into English, and analysed by the researcher. Though most Tablīghi events and sessions are open to all Muslims, the researcher sought informed consent from movement's leaders to participate and conduct field research. Unless stated otherwise, all names used in the paper are pseudonyms; anonymity and confidentiality was maintained through the research.

12 Population and Housing Census Report 2009, 
sectarian affiliations. Large sections ascribe to moderate Sunni traditions with strong affiliation to Shafi i School of jurisprudence. Members of the movement constitute a minority missionary group with high visibility in Muslim public spaces due to frequent itinerary and upsurge in membership. Tablīghī Jamā'at is active in most parts of northern Kenya and the coast. The north is home to speakers of Cushitic languages such as Borana, Gabbra, Burji, Garre, and Somali. ${ }^{13}$ These communities are largely pastoralist and highly patriarchal. They are largely Muslim, although practical adherence to Islam differs among them. Among the Borana, the place of women and men and how they ought to behave is largely influenced by traditional norms and customs. Islam as a practised religion is relatively an urbanized phenomenon. Hence mosques and madrasas provide sites for socialization and religious change. It appears prudent to provide a brief history of Tablīghī Jamāat before embarking on its reconfiguration of masculinities.

\section{The Coming of Tablīghī Jamā'at in Kenya}

Tablīghī Jamā'at is a pietistic missionary movement founded by Maulana Muhammad Ilyas, a Deobandi educated Muslim scholar in 1926 in Mewat, near Delhi. ${ }^{14}$ Mewat was occupied by the Meo community that was then characterized as being nominal Muslims drenched in un-Islamic practices such as Hindu worship of deities, cults of the veneration of saints, nonobservation of Islamically ordained duties, and failure of the religious scholars to guide the community out of the deep political, economic, and

http://www.knbs.or.ke/Census\%20Results/Presentation\%20by\%20Minister\%20for\%20Pla nning\%20revised.pdf.

13 H.G.W. Arero, Keeping the 'Peace of Borana': Aspects of Peace and Conflict in Shifting 'Indigenous' Systems of Northern Kenya, Norwich: University of East Anglia 2002.

14 Tabligh means conveyance or propagation, jamā'at means a society, group, or party. Tablīghī Jamā'at is motivated to send out lay preachers by prophetic traditions that celebrate propagation of Islam. However little knowledge one has, a legitimating verse in the Quran urges every Muslim to 'enjoin good and forbid evil' as members of God's best community (Quran 3:110). B. Ingram mentions that Deoband madrasa is 'arguably the most intellectually influential and historically consequential centre of Islamic learning outside of the Middle East. Founded in 1867 in the wake of a failed revolt against British rule a decade earlier, the Deoband madrasa aimed to reassert Muslim intellectual prominence amidst a sharp decline in Islamic political power in the Indian subcontinent.' B. Ingram, 'Sufis, Scholars and Scapegoats: Rashīd Aḥmad Gangohī (d. 1905) and the Deobandi Critique of Sufism', Muslim World 99:3 (2009), 478. 
religious uncertainty. ${ }^{15}$ It was also established to counter the Hindu reform movements such as Arya Samaj that targeted to reverse the nominal Meos from Islam back to Hindu religion. Many revivalist organizations targeted the political and social emancipation agenda in the face of British colonial rule - unlike Tablīghī Jamā'at, which took an apolitical stance and focused solely on spiritual revitalization among the masses.

Tablīghi Jamā'at came into Kenya around 1956, largely through contacts with Kenya's Asian Muslim communities from the Indian Subcontinent. ${ }^{16}$ Mercantile Indian Ocean traffic brought traders of various origins to the coast of East Africa. Among early settlers and traders were Indians of various religious persuasions. ${ }^{17}$ British Colonial administration also brought a large number of Indians as indentured railway labourers to construct the Kenya-Uganda Railway from Mombasa to the shores of Lake Victoria at the turn of the twentieth century. A number of the labourers went back home while others made Kenya their home. Subsequent migration increased the population of this diasporic and heterogeneous community. The Kenyan Asians are relatively wealthy traders and industrialists. Various Muslim communities are represented within them, including Ismailis, Ithna Asharis, Ahmadis, Sunni Memmons, Punjabi Muslims, Cutchis, Baluchis, and Kokanis. It is among the Sunni groups from the Kenyan Asian community that the Tablīghi Jamā'at found a transnational connection.

Prominent Kenyan South Asian personalities such as Hajj Wali and the late Sheikh Darwesh facilitated the community's growth in Kenya. The Jamā'at has immense presence in northern Kenya, the Coast, and Nairobi. Among the Borana community of Isiolo and Moyale, the Jamāat has an active history of over 15 years. ${ }^{18}$ Over the years, Kenya has emerged as a hub for the regional coordination of Tablīghi activities in the greater Eastern and Central Africa. By the mid-1980s a significant number of local

${ }^{15}$ See M.K. Masud (ed.), Travellers in Faith: Studies of the Tablīghi Jamā'at as a Transnational Islamic Movement for Faith Renewal, Leiden: Brill 2000, 3-11.

${ }^{16}$ Sermon by Sheikh Naushad at Bait ul Maal, Nairobi: 18 April 2009.

17 See C. Salvadori, Through Open Doors: A View of Asian Cultures in Kenya, Nairobi: Kenway Publication 1989 and C. Salvadori, We Came in Dhows, Nairobi: Paperchase Kenya 2000.

18 Some informants date the arrival of the first Asian Tablīghi groups in the early 1970s. Aw Boru, an elderly Borana Tablīghi from Waso, recalls initial travels with such groups in the 1970s and 1980s. The subsequent construction of the first madrasa in Kinna by Kenya Asian Muslims from Meru Town also heralds the first active engagement of local Muslims in the growth of the Jamā'at in the area in the 1970s. Personal conversations with Hassan Doda, Isiolo: 4 April 2009, and Aw Roba, Kinna: 9 September 2009. 
Asian and African Muslims were recruited into the movement and became its representatives and proselytizers.

Tablīghī Jamā'at as a transnational Islamic movement has an active presence in several countries. The fact that it does not keep membership lists makes it hard to estimate its global reach. It is run by laypeople, voluntary, apolitical, and pietistic. ${ }^{19}$ It markets itself as a preaching party that seeks to bring nominal Muslims to the path of practical faith as based (by their definition) on the life model of the Prophet, a process and product that is related to the inculcation of a new habitus. There is a general tendency within the movement to argue that Muslims have neglected their faith and that religious scholars have fallen into inertia. It requires that ordinary believers constitute a preaching group and travel for a stipulated number of days so as to transform their practice and remind others of religious obligations. It shuns materialism, sectarianism and other forms of classification. It wrestles with the duty of preaching ( $d a$ ' $w a)$, which has always been the preserve of the 'ulamā as an ultimate duty of every Muslim, male and female, who, by teaching others, may get a deeper knowledge of the fundamentals of Islam. ${ }^{20}$

Central to the ideology of the movement is the role of travel as the most effective tool of personal reform. The main teachings of the movement are summarized under six principles: 1 . article of faith (shahada); 2. five daily ritual prayers (salat); 3. knowledge (ilm) and remembrance of God (dhikr); 4. respect for every Muslim (ikram-i Muslim); 5. emendation of intention and sincerity (ikhlas-i niyat); 6. spare time (tafriq-i waqt). ${ }^{21}$ The last principle is the hallmark of the movement, also known as khuruj fi sabillilah (going out for the sake of God). It involves volunteers, mostly men, sparing time and resources to travel away from home for different durations such as 3 days, 10 days, 40 days, 4 months, or even a year. As we shall see later, such absence away from home has direct consequences on discourses regarding masculinity.

${ }^{19}$ See Masud, Travellers in Faith, xvi, and R. Dickson, 'The Tablīghī Jamā'at in Southwestern Ontario: Making Muslim Identities and Networks in Canadian Urban Spaces', Contemporary Islam 3:2 (2009), 99-112.

20 Tablighi informants posited that the obligation of inviting others to the faith is not fard kifaya (duties that can be done by few on behalf of the umma, global Muslim public), but fard ayn, compulsory for each and every individual. Personal conversations with Mahmud Qallu, Moyale: 2009, Aw Kombola, Isiolo: 2009, Mohamed Arero, Nairobi: 2010, Hassan Doda Isiolo, Merti, Nairobi: 2009, 2010, 2011, Aw Boru, Kinna: 2010, and Sheikh Abdi, Nairobi: 2010.

${ }^{21}$ Y. Sikand, The Origins and Development of the Tablïghi Jama'at (1920-2000): A Cross Country Comparative Study, New Delhi: Orient Longman 2002. 


\section{Who is a Tablīghī in Northern Kenya?}

Tablīghī Jamāat attracts individuals from all backgrounds. However, it attracts few religious scholars. By blurring the boundaries of religious authority, the movement has opened the gates for all willing men to partake in preaching. Three aspects of this lay approach give testimony to how these groups of self-organized lay preachers appropriate sacred spaces. First, it lowers considerably the level of knowledge required for giving a sermon; second, it allows for sermons to be delivered in the (vernacular) language best understood by mosque attendants; and third, it limits the agenda of reform to the most fundamental level, thus avoiding doctrinal and jurisprudential matters.

A survey of the current crop of Tablīghi leadership in the towns of Moyale, Isiolo, and Merti reveals that a significant majority have good secular education, with many working as government employees, teachers, nurses, NGO workers, and small-scale traders. A number of retired civil servants and regular elderly mosque attendants are also found in its fold. This category of people, though often regular mosque attendants, has limited access to the pulpit for religious instruction. Before the spread of the Tablīghi Jamā'at, the use of the pulpit was fiercely regulated and monopolized by imams, the custodians of mosques. Only select scholars could give speeches, which rendered a large section of willing lay preachers with little outlet to participate in the revivalism of faith.

These laymen found in the movement a perfect forum to redeem their religiosity. They competed for the use of sacred spaces for religious instruction, appropriated convincing religious narratives to legitimize their practices, mobilized new members into their fold, and routinized certain religious actions at home and in their local mosques as a mark of piety. Just like the 'ulamā of the mainstream Islamic traditions, who are a product of translocal apprenticeship, the non-'ulamā men of the Tablīghi Jamā'at also network with the world beyond their villages and towns. They travel with and receive translocal preachers from foreign countries and neighbouring regions and attend transnational gatherings in places as far away as Nairobi on a regular basis. These Tablīghi men, unlike the 'ulamā of mainstream traditions, add a new dimension to the practice of religious journeying and knowledge. The movement is hence a conduit for transmission, negotiation and adoption of new forms of masculinities and religiosity. The resultant masculinities, though similar to the pre-existing Islamic versions, are also different as they are envisioned and developed in unique sociocultural circumstances in the Indian sub-continent. 
Although every man could ideally travel for khuruj fi sabililah (missionary tours), or khuruj, as mainly used by the Tablīghis, a certain amount of money is required for food and other essential expenses. The costs are often very little and differ from region to region. In Kenya, a three-day preaching tour costs approximately $€ 3,10$ days $€ 10,40$ days $€$ 40,4 months $€ 100$, and so on. Although the costs may appear meagre, in a region with a high unemployment rate and frequently ravaged by drought and famine, only select 'pious' men would be able to allocate their income for such travels, such as secular-educated men in regular employment and small-scale traders. The movement encourages participation in its daily, weekly, and monthly activities at the mosques and reinforces group commitment through regular individual travel activities. The celebrated idea of self-financing minimizes financial assistance for travels between members but also on the other hand increases commitment of those ready to sacrifice incomes for the movement's practices.

Regular practices further bond these non-'ulamā men into an egalitarian society based on shared religious concerns and experiences. The lowest unit through which these laymen are socialized as an alternative religious class is a mosque-based unit (masjidwar jamā'at). 'The mosque constitutes a source of identity and venues for re-enactment of Tablīghī practices,' says Ahmed from Al-Rahma mosque of Isiolo. Each mosquebased unit is composed of members ranging from a few to a dozen regular Tablīghìs. In most cases, the Tablīghi do not have mosques of their own and they constitute councils parallel to the mainstream 'ulamā mosque management. Through a mosque-based Jamā'at, the Tablīghis aspire to carry out what is commonly known as panch amal (Urdu), or amali tano (Swahili). Panch amal refers to five religious practices to be carried out by Tablīghi-friendly mosques in order to obtain 'the characteristics of sacred spaces of pristine Islam. ${ }^{22}$ The practices include mashwera (daily consultative meetings), ta 'lim (a weekly religious instruction), jowla (neighbourhood patrol around the mosque to mobilize people for preaching and travel), fikru jamaa (weekly consultative meeting involving all the mosque-based units in a town), and finally khuruj shahri (recruitment and travel of at least one three-day preaching team from each

22 When asked about the rationale behind the practices of panch amal, Hassan Doda explains, 'Akamin misajidi keen misajidi Rasulatif misajid as'habota fakaat? Misajid Rasulatif misajid as'habota washann kesat argan ... Amal shannan! [Borana: How can our mosques be like the mosques of the Prophet and his companions? The mosques of the Prophet and his companions were characterized by five traits ... they are five practices!] Personal conversations with Hassan Doda, Isiolo: September 2009. 
mosque every month). It is incumbent upon a mosque-based unit to visit and encourage Tablīghīs from neighbouring mosques to establish similar units and perform the practices of panch amal. The target, hence, is to ensure that as many mosques as possible subscribe to the Tablīghi notion of sacred spaces. These temporal and spatial practices play a fundamental role in re-socialization of the Tablīghi men and gradual reconfiguration of their self-perception as men of religious piety and practice. With more time spent in common religious spaces with fellow Tablīghis, the movement's endless programmes slowly alter their everyday practices as regular mosque attendants, as members of their local communities, as heads and members of their households.

Re-enactment of panch amal in mosques by Tablīghi men is a strategy to ground their practice in their local mosque and in a way to contest its ownership and use. Tablīghis have over time dominated the use of certain mosques, turning them gradually into an operational base for their form of proselytism. The relations between the Tablīghi men and mosque custodians are often tense since modification of the religious practice of the laity is at stake.

All mosque-based units in a locality constitute sub-halqa units. Approximately ten sub-halqas form a halqa. In the Tablīghi religious geography, Kenya has three regional halqas: Garissa, Mombasa, and Nairobi. Isiolo and Waso sub-halqa is under Nairobi halqa while Moyale and Marsabit sub-halqa fall under Garissa halqa. Such reterritorialization enhances the ease of travel and networking between Tablïghi men based in different parts of Kenya. It surpasses the religious networks of local 'ulamā, rendering them less effective in transforming everyday religious practices of the people. At each level of Tablīghi 'faith bureaucracy', leadership positions are to be filled by qualified and committed Tablīghīs. ${ }^{23}$ The leadership positions are open only to men. The ordering of the spatial zones of operation and the resultant fluid bureaucratic structures in charge of its da'wa administration is one of the novel ways of organization of men involved in the movement.

The need for competent leaders of units from local to national levels raises a fundamental point in the construction of Tablīghi masculinity. Not all men within the movement have equal access to power and authority and all the attendant privileges associated with it. Despite

${ }^{23}$ See D. Reetz, 'The Faith Bureaucracy of Tablīghī Jamā'at: An Insight into their System of Self-Organization (Intizam)' in G. Beckerlegge (ed.), Colonialism, Modernity, and Religious Identities: Religious Reform Movements in South Asia, Oxford, Delhi: Oxford University Press 2008, 98-124. 
the claim to equality and egalitarian principles, hierarchy is strong within the movement. ${ }^{24}$ In this 'faith bureaucracy', the more an individual allocates time for travel, the more he embodies Tablīghi practices, thus slowly refining his piety and becoming an authority among his peers. The opinion of such senior regulars often counts during meetings. Lowest in the rank in the Tablīghi bureaucracy of influence and power are judud, the newest recruits. The novices are dispossessed of the power to preach unless in areas where the locals themselves are illiterate. These juhud men can only be led and their habitus transformed. Their worldview is guided so that they do not 'invent' innovative practices and ideology. After a number of travels for preaching, the novice raises in status to become a regular Tablīghi. Several years of regular travels and participation within the movement elevates such a committed man to the rank of qudamah. Such a man literary knows every other regulars in the sub-halqa. He becomes a committed dai, a celebrated religious caller. A qudamah is also at times referred to as purane sathi (old comrade in Urdu). He embodies the very idea of being a Tablīghī man in terms of clothing, manner of speaking, and regularity of attendance in all movements' events and activities, communal and individual. One can say that tabligh become his lifestyle. Unlike in the local Cushitic forms of masculinities and strong patriarchal systems that place greater emphasis on seniority based on age and similar local Islamic understanding that imbues power and prestige among men by their religious learning, Tablīghī masculinity proposes a competing alternative that favours one's access to power, religious piety, self-realization and leadership position based on the length of travel experiences and embodiment of Tablīghi teachings.

The men involved in the movement as regulars are kept busy by several activities. It is typical of such men to desert their old liberal and care-free colleagues for the pious company of fellow Tablīghìs. One stops 'hanging out' with friends in video halls, where popular English premier league matches are broadcasted to football fans via satellite dishes. Friends are mainly drawn from the movement, who are frequenting specialized meetings and general public gatherings at the local and the translocal level. Commenting on such visible transformation of men in the movement, one informant, himself an aspiring Tablīghī, observes:

Tabligh is a path praised by God. It is a path that is taken by very few. To be in that group, you are blessed. The main reason why people don't love tabligh is that you become sofigi [a wandering mystic]. You delink yourself

24 Ibid., 99. 
from the rest of the world. As for me being a non-Tablīghī, people are happy the way we are. We roam the streets. We do all we want. We discuss politics and other social issues. You are seen as a guy about the town (Moyale). When it comes to tabligh, it's your job, your family, at night in your ibadat [prayers]. There is nothing between you and God. You think of heaven. You think of death. But currently as the ordinary youth think of scholarship and education, the ones in tabligh are thinking of heaven and how they can propagate the faith. People say that you have become Sufi. That you have lost network [to become delusional]. You become secluded. You fear gossip. Some say you become like garib [member of Husseiniya Sufi order from Ethiopia renowned for poverty and selflessness]. It is a risk that many people would not take as they will lose social life. ${ }^{25}$

\section{Not so 'Manly': A Glimpse at Protest Masculinity}

Tablīghī Jamā'at instructs its members to avoid political discussions. ${ }^{26}$ Being apolitical has also been mentioned as having immense political implications. ${ }^{27}$ The members blame everything from corruption to communal 'powerlessness' in face of modernity on the lack of commitment to practical Islam. Hence the solution is seen as nothing short of a complete change of heart to live a life modelled after the Prophet Muhammad. The official religious scholars get the brunt of such condemnations for their lack of concern and laxity. Discussions on matters political are dismissed as mundane and unnecessary. Peter Mandaville posits that Tablīghī Jamā'at belongs to those Islamic movements that do their best to ignore the state or operate as if it does not exist. More specifically, the Tablīghi model is 'in essence, an inverse normative model in which the good does not emanate from an ethical institution (i.e. the state) but rather from an emphasis on the collective power of the ethical "self".,28

Why would shunning politics constitute a threat to hegemonic masculinity? Most 'ulamā in the region argue that religion and politics are inseparable. But the movement strongly discourages discussion of matters that deal with politics. This includes concerns regarding local communities

${ }^{25}$ Personal conversations with a group of Muslim youth in Moyale, comments by I. Ali, Moyale: September 2009.

${ }^{26}$ See A. Horstmann, 'The Tablīghī Jama'at, Transnational Islam, and the Transformation of the Self between Southern Thailand and South Asia', Comparative Studies of South Asia, Africa and the Middle East 27:1 (2007), 26-40.

27 See Y. Sikand. 'The Tabligh Jama'at and Politics: A Critical Re-Appraisal', Muslim World 96:1 (2006), 175-95.

28 P.G. Mandaville, Transnational Muslim Politics: Reimagining the Umma, London: Routledge 2001, 146. 
such as issuance of national identity cards, the impact of Kenya's government anti-terror programmes on the Muslim community, constitutional debates on the place of Muslim personal law, problems of representation in governmental bodies, equitable resource allocation, and ethno-religious conflicts. Their rhetoric stays aloof of all these worldly matters and focuses on spiritual transformation of individual believers through preaching tours and strict adherence to practical Islam. In retrospect, the radical configuration of masculinity by the movement lay not in new forms of religious mobility and concomitant experiences but in its insistence to question and suggest alternatives to the primordial modes of expressions of defence, membership and support to local Muslim communities' causes. This subtle pacifism - or more specifically, the avoidance of most discourses that relate to power politics and sociopolitical activism - is extolled by the Tablīghis as a virtue associated with the idealized men of piety of the formative Islam and runs counter to the virility and readiness to defend the pastoral rangeland and stock by the Borana speaking communities in old times. Also it negates the increasing entanglement of religion and politics and activism in Kenya's religious communities.

Usul ishirin, 20-point principles that form the outlines of what is allowed and what is forbidden while on preaching tours. These do's and don'ts have bearing on the establishment of Tablīghi masculinity. Each team of volunteers is always reminded of these rules before they go out for preaching. The rules are divided into five sets: four things to be done in plenty; four things to be reduced drastically; four things to force oneself to do; four things to be far from (partially forbidden); and finally four things not to be talked about (totally proscribed). Proscribed acts include siasa (politics), ayubu nas (peoples' faults), ikhtilāf 'ulamā (argument with religious scholars over doctrinal issues), and ibta wa jidda or kibr (pride).

Politics and related matters are seen not only as worldly but also divisive by the members of the movement. More importantly, being apolitical makes it easy for members of the movement to travel and to establish operational bases and self-sustaining units without raising suspicion or censorship from most governments. The avoidance of politics is, however, interpreted by rival religious movements and traditions that lean toward salafism as acts of 'unmanly' cowardice, self-serving, and selective interpretation of Islamic teachings. ${ }^{29}$ Sheikhs often cite examples

${ }^{29}$ Opponents invoke Quranic verses that classify such groups as unbelievers for believing certain parts of the scriptures and ignoring others. Other 'ulamā assert that because of its selective interpretation the Tablīghī Jamā'at is among the 72 heretical sects destined 
of how being apolitical means playing right into the hands of the 'primordial enemies' of the faith, such as the Western powers and culture. The opponents accuse Tablīghi Jamā'at of making the youth of the umma soft, emotional, and outer-worldly. To counter the call for Tablīghi proscription of politics, rival traditions seek legitimacy within the Prophetic tradition, citing the necessity of power politics and military engagement. Sheikh S. Bafana, for example, sums up the apolitical nature in a stronglyworded polemic against the movement:

If you want clash with the people of Tablīghi Jamā'at, speak about politics! Just say that the Prophet PBUH was commander-in-chief of army ... just say that the Prophet PBUH was a head of state and a president ... just say that the Prophet was a governor ... say that the Prophet was a qadi [judge] ... they would say that these are worldly matters, so leave it aside please $!^{30}$

Bafana condemns the inner reform agitated by the movement as a sham. He argues that the movement relies on inauthentic and fabricated sayings of the Prophet that call for inner jihad, a perpetual struggle against one's own soul, vis-à-vis political and military engagement against oppression and un-Islamic regimes. The movement is hence accused by opponents as neglecting masculine responsibilities especially in protection of the religion. By rendering the religious practices of Tablīghi Jamā'at heretical and innovative, the opponents delegitimize the movement in the eyes of the general laity. Bafana aptly observes:

Apart from substituting jihad with khuruj fi sabililah [preaching tours], they have gone to the extent of changing the term jihad and called it juhud! [Concerted efforts] If you inform that here what is required is jihad, they would object and say that what is needed is juhud. Let's push juhud! If you tell them we need to combat this or that, they would argue that we need just juhud. Jihad has become juhud. It is not juhud, it is jihad. What did the Prophet say: al jihad mafin ila yawm al qiyama ... that jihad shall continue until the day of judgment. Then they claim that it is juhud, not jihad. ${ }^{31}$

for hell because they not only stay aloof from everyday problems of the umma but also allow illiterates to preach, falsely interpret the basis of Islamic monotheism, and desert responsibilities required of a man through unwarranted travels. Recorded audio sermon by Sheikh Umal, Nairobi: 2010.

30 Sheikh Said Bafana, Criticism against the Tablīghī Jamaat, Video CD, Nairobi: Wa'Haqq Films Production, August 2006. The polemic video systematically deconstructs the movement as deviant. The speaker fuses his interpretation of Quran and the Prophetic traditions to make these points. The video is in Swahili and Arabic and transcribed into English by the author.

31 Sheikh Said Bafana, 'Criticism against the Tablīghī Jamaat.' 
The Tablīghi avoidance of political activism is further reinforced by docility and a non-aggressive approach to proselytizing. The opponents of the movement accuse them of effeminization because of their non-aggressive responses to conflict situations, their emotional appeals, and excessive humility. Tablighi rules, like the avoidance of doctrinal discussions with religious scholars, save members from unnecessary controversies with the religious status quo. Despite explicit avoidance of militancy and overt demonstration of masculine power, Tablīghīs employ a vast register of 'military terminologies' in reference to their practices. The spatial reterritorialization strategy resemblances political administrative units. Tablīghī hierarchy mirrors bureaucratic organization of modern political and social bodies. The movement talks of their mobility practices such as jowla and gusht as a form of military excursions, albeit peaceful ones. Travel groups are in fact organized metaphorically as such. At times titles such as amirs or jemedars and the powers the elders and leaders yield within the movement are overt indicators of the influence of contemporary political and fundamentalist movements.

Each preaching team is composed of 10 to 15 volunteers of varying Tablīghì experience and led by an amir (leader), a seasoned Tablīghī, who is selected and appointed before departure. The amir as the team leader of a travelling group must be respected at all times. He exercises immense power over the other men in the travelling team and has final say on allocation of duties, finance and management of time. He listens to every opinion of the group during deliberation and makes final decisions. Such powers are, however, moderated through wise decision, humility, and consensus building. Amirs, whether in travelling teams or at different levels of Tablīghī administration, are 'first among equals' to whom the position of authority is delegated based on years of commitment. In fact, during national conventions such as Nairobi ijtimai, the amirs of different subhalqas and qudamahs have the privilege to deliberate on pertinent issues of the movement away from the hundreds of ordinary followers, which clearly reflects unequal possession of power and privileges among the Tablīghī men.

While travelling, Tablīghī men are expected to acquire a strong set of domestic skills. ${ }^{32}$ Most of them learn for the first time how to wash clothes, cook and clean. Cooking and related hospitality duties are referred to as khidma. It is the first duty to be delegated in a consultative meeting immediately when a preaching team arrives in an area. Other duties, such

32 See Mandaville, Transnational Muslim Politics. 
as preaching at the local mosque or being part of a recruitment team, come second to the cooking work. Cooking absolves the individual from other works of proselytizing such as preaching and recruitment that at times exposes one to latent ridicule from fellow Tablīghīs, resident 'ulamā, and ordinary mosque attendants. To avert dissatisfaction due to badly cooked food from inexperienced fellows, there is the unwritten rule never to criticize team members for their cooking or to praise one's own skills. Eating is communal, hence eliminating the hierarchy between the leaders and the followers. The cooking and household chores among Borana speaking communities have been culturally associated with the female. It poses the greatest threat to masculine pride and is therefore perceived as a selfless sacrifice and marked by Tablīghīs as the most spiritually rewarding act while on travel.

The daily foray to the market of Tablīghi men cladded in Muslim robes while haggling over prices of onions, milk, and tomatoes is most picturesque. Ordinarily, in this part of the country, the duty of buying food from the market is associated with women, since the market is an extension of female domestic space. There are male shopkeepers, butchers, and kiosk owners, but the business of selling and buying mboga (vegetables and other comestibles) is dominated by women. For respectable men of influence in the local communities, to buy daily rations on behalf of fellow Tablighī men is undoubtedly a challenging notion of a 'real' man.

Hands-on experiences with managing 'kitchen' affairs inculcate in the Tablīghi men a greater insight into the challenges of everyday livelihood strategies at home. For this reason these men are seen to feel more sympathetic, less demanding, and gentler toward the challenges of carrying out domestic chores by women at home. Conversely, Tablīghi women have to learn to lead the household in absence of their husbands, a kind of reverse household headship that could not be imagined in patriarchal societies like these. It is not uncommon for committed Tablīghis to be absent every year from their homes for periods of no less than four months. Shazia Kamil says:

Because men are gone for most of the time, they learn to maintain their own living spaces by cooking and cleaning. At the same time, when women remain behind with their children, they assume the traditional male roles of protector and sometimes breadwinner of the household. Moreover, they are encouraged to participate in the Tablīghī Jamā'at themselves. Thus, 
women also partake in dawah activities, where they invite Muslim females to learn about Islam and dedicate time to community service. ${ }^{33}$

\section{Bringing Tablīghī Jamā'at Home: (Dis)Empowering Patriarchy}

Yoginder Sikand notes that the movement provides women with new sources of mobility and a significant instrumentality within the family and the neighbourhood as active agents in the Islamization process. ${ }^{34}$ Hence, Tablīghi discourse on women has a hidden critique of certain traditional notions of femininity and domesticity. The practices mentioned above give new instrumentality to a dimension of femininity and masculinity hitherto lacking: it allows men and women to travel together for preaching tours and women to lead temporarily the homestead, engage in text reading at home, and other collaborative social practices. Let us explore a few of these issues in relation to the construction of Tablīghi masculinity.

Masturat jamā'at, a spousal preaching tour, is a special kind of travel in which four to five couples are away from home from three days to a few months. It allows women to engage in khuruj, a spiritual journey that has kept their husbands and brothers away from their matrimonial homes. Often it is the wives of senior regulars who accompany their husbands on such travels. In an area where adherence to daily religious practices among the women is largely lax due to inadequate knowledge of Islam and where women have been relegated from public religious participation in mainstream orthodoxy for decades, the idea of travelling and preaching, even if it is to fellow women, can be undoubtedly liberating. Lacking access to the men-dominated religious public space, Cushitic women have often participated in ayaan and zar possession cults, preservation of indigenous religious rituals such as buna qalla (sacrifice of coffee beans for fertility and flow of divine blessing) and performative, quasi-Sufi dances and healing sessions of the Sheikh Hussein brotherhood. ${ }^{35}$ The transformative elements of masturat jamā'at may be seen in light of these traditions, yet it may also reinforce patriarchal control of women. In masturat jamā'at, the rules of modesty are observed in the strictest terms possible. In fact, far

${ }^{33}$ S. Kamal, The Tablīghī Jamā'at: A Question of Gender Equality, Altmuslimah.com, http://www.altmuslimah.com/a/b/mca/4221/ (accessed 14 April 2011).

34 Y. Sikand, 'Women and the Tablīghī Jamā'at', Islam \& Christian-Muslim Relations 10:1 (1999), 41-52.

35 See I.M. Lewis, Religion in Context: Cults and Charisma, Cambridge: Cambridge University Press 1986, M.I. Aguilar, Being Oromo in Kenya, Trenton, NJ: Africa World Press 1998 and U. Braukämper, Islamic History and Culture in Southern Ethiopia: Collected Essays (Göttinger Studien zur Ethnologie 9), Münster: Lit 2002. 
from reconfiguring gender roles, most pietistic movements appear to entrench more literal and puritan interpretations of female and male social interactions especially while on preaching tour. ${ }^{36}$ Hassan, a frequent participant in masturat jamā'at, affirms that

the wife must accompany the husband for masturat jamā'at with clear adherence to the rules of awrah [modesty and bodily concealment]. She should even wear socks, have niqab, have hijab and so on. They should be guarded by decency and simplicity. They are urged to wear hijab and simple Muslim dress, and not jewellery and expensive cloths. Their clothes should be simple and down to earth. ${ }^{37}$

The body, especially the female body, has to be continuously policed while on travel. In addition, the female voice has to be restricted in line with conservative interpretations of Islamic teachings. The women can only preach to local women and often in a low voice, and are not allowed to preach to men. Their preaching, unlike men's, must be done conversationally. Often senior Tablīghī men's wives encourage fellow women to change their behaviour in a non-authoritative way without standing up like men. Even though travelling together for preaching, husbands and wives must sleep in separate quarters: men at the local mosque and women at a house of a local Tablīghi male host. The hosts are expected to reside with fellow men at local mosques for the period the women are based at their home. Men act as security for the women in rotation so that the borders of gender relations are not infringed upon by other men. ${ }^{38}$

Local women gather at such venues to listen to expositions of the six principles, virtues of good home management, and fundamental spiritual benefits of strict adherence to the rules and practices of Islam. Men in the group preach to their own women and local women, but only behind a curtain, further reinforcing masculinity. They do this every morning in a religious instructional session called ta'lim. However, the egalitarian nature of the masturat jamā'at is enforced through equitable sharing of khidma responsibility. Remarkably, wives and husbands by turns share cooking and other chores on behalf of the preaching team.

While every man ideally has a chance to travel provided he has the money to cover the cost of travel and food, every willing woman cannot

\footnotetext{
${ }^{36}$ See also S. Mahmood, Politics of Piety: the Islamic Revival and the Feminist Subject, Princeton, N.J.: Princeton University Press 2005, 106-108.

37 Personal conversations with Hassan Dima, Abdub Boru, Kinna: October 2009. 38 Ibid.
} 
partake in masturat jamā'at. Single women, whether unmarried, divorced, or widowed, may not travel unless accompanied by a male guide, a muhrim, a male relative not marriageable to her. Co-wives cannot travel together to avoid unnecessary clashes and rivalry. Expectant women nearing delivery, sick women, and breastfeeding women are discouraged from such travels. These proscriptions notwithstanding, masturat jamā'at offers a rare opportunity for women to partake in preaching and all the related duties largely monopolized by men. It appears to empower local women, who form the bulk of the audience, to nominate themselves and their husbands for the next travel. The husbands, though not obliged, often take on the challenge and travel once informed of the nomination. These kinds of tours delimit creativity and capacity of the women participants to make decisions relating to their travels and practices as set rules on Tablīghi practices govern such outings. It is innovative preaching strategy and practice for the women who participate in it. In a way, it nevertheless reinforces the patriarchal role played by the men in such societies because women largely remain enactors of the norms and practices of the movement.

Tablīghī Jamāat knows two forms of religious instructional sessions: ta 'lim fil bayt (home-based) and ta'lim fil masjid (mosque-based). The former is for the family, the latter for the general audience composed of regular male mosque attendants. The movement also has countless numbers of talks. However, the men are expected to bring religious instructions to their homes and are encouraged to do so on a daily basis. The idea behind ta' lim fil bayt is that the immediate family is the smallest and the most essential unit of faith renewal. The reform of womenfolk is tied by the Tablīghi Jamā'at to the entrenchment of lasting change in behavioural patterns and religious adherence of society. ${ }^{39}$ The home of Tablīghi man is thus linked as the most basic unit to the transnational network of fellow lay preachers. Abdu mentions that ta' lim fi bayt connects the home to the mosque, and the mosque, in turn, is linked to other mosques worldwide through collective activities.

The ta' lim fil bayt targets largely the nuclear family. Sessions involve readings from the core Tablīghi texts (such as Fazail-i A'amaal [Virtues of Actions] with themes extolling spiritual benefits accruable from recitation of the Quran), constant remembrance of God, proper and timely

39 Rashid, quoting a popular saying, mentions that 'transformation at the level of the family is crucial and the faith will be firm in the region. If a woman becomes well transformed in the faith, it is better than 70 men.' Group discussions with Rashid, Abdu and Abdi Bashir, Moyale: June 2010. 
performance of prayers, and memorization of the six Tablīghī principles. ${ }^{40}$ $\mathrm{Ta}$ 'lim fi bayt is concerned with themes of proper Islamic upbringing of children (tartiib al awlaad) and home management. It is also concerned with how a woman can fulfil her duties to her husband, her neighbours, and do the five daily prayers in her home, and how she can preserve and cover herself inside and outside her home through hijab, that is, concealment of her body through proper Islamic dressing. ${ }^{41}$ All these teachings and entrenchment of religious practices have the net effect of embodying greater adherence to the ideal Tablīghi gender roles and norms.

To mitigate masculine domination, the men in Tablīghi Jamā'at are encouraged to allow for proper ownership of these instructional sessions by women and children. The men often give leading roles to their wives to read a text or two from the Tablīghi core books. On a rotational basis, children are also drawn into chairing the session. Thus, in a sense, hierarchy is abolished and authority delegated, albeit only temporarily. This temporal delegation of household leadership in group activities such as text reading falsely gives the impression of democratization of the Tablīghi home, but in reality it allows for overt masculine domination as the agenda and practices to be re-enacted had already been decided by the man, often instructed by other Tablīghī men.

Inculcating Tablīghi ideology at home serves, at least indirectly, the interests of men. It is easier for wives and children of such transformed homestead to allow their husbands and fathers to travel for preaching tours. Misrecognizing the underlying patriarchal manipulations, wives become complicit in allowing their spouses to make spiritual journeys for up to four months for the sake of the movement. ${ }^{42}$ Bashir, a regular Tablīghī, reformulates the above point in this manner:

Coming back to the reforms at home is important. You know our people [Borana] say that the gods of the women are the husbands and that the gods of the children are the fathers, so the reform would change their

40 Rashid, commenting on the procedure and the benefits of the session at home, states that 'ta' 'lim at home is daily. Time is arranged. There is tarteeb (procedure) and adab (etiquette). Once you settle down for the ta 'lim, you thank Allah for the gathering. You then read a hadith or two related to that. You mention the spiritual rewards of such a gathering. This will motivate the household members to keep attending. They are driven by the statements that if you attend you shall gain this or that from Allah. You also add that the deeds that Allah loves most are deeds that are routinely carried out. When you emphasize this the house members would want it more and more. It becomes a regular thing.'

41 Personal conversation with Hassan Dima, Kinna: October 2010.

42 See P. Bourdieu, Masculine Domination, Cambridge: Polity Press 2001. 
hearts to the real God, Allah. ${ }^{43}$ This will bring about tawakul [complete reliance on God]. The whole family now relies on God and you are now less pressurized. Then you will get the time to serve God. You can actively participate in da' wa [calling people back to the faith]. They [women and children] can all now serve God. They understand the importance of faith and they shall be guided by the faith. Now this gives you a lot of freedom to engage in travel for Allah. You can now comfortably go for 4 months or 40 days. It is possible they understand that it is God who provides (and not the man). ${ }^{44}$

Closely related with ta' lim fil bayt is shūrā fil bayt (home-based consultative meetings). Shūrā means consultation. It is supposed to be carried out on a daily basis. The family agrees consensually to set a specific time for it. Then topics of discussions may range from resolving domestic disputes to talking about the school performance of children and impending travel of the man of the house. Tablīghi Jamā'at, in a bid to avert disagreement between spouses, encourages prior deliberations about upcoming travels. However, only a handful may ask their womenfolk for permission to go. A Tablīghi man could have pledged to travel every year at least for 40 days, a pledge known as sanawi. When such time comes, he would be obliged not to let down his fellow Tablīghī men.

The opponents of the movement cite frequent absences of Tablīghi men as a threat to masculinity. Rival religious scholars delegitimize such long travels as latter addition to the faith, as neglectful of masculine responsibilities, and as wasteful of family resources. Opponents cite examples of broken marriages, children dismissed from school, and job termination of Tablīghi men by employers due to unwarranted travels. These, they say, are clear signs of the hazards of the movement. Furthermore, Tablīghī men have

argued to 'devalue the public realm' by pointedly avoiding politics. They hence do not claim any particular position or space of masculine power or virtue. At times Tablīghī men have come in for criticism from other Muslims

${ }^{43}$ Borana folk understanding of masculinity places lordship of men over women. However, the informant echoes the same sentiment and robs women of the agency to develop reliance on God on their own, unless mediated by their menfolk. Asma Barlas notes that 'masculinizing God is the first step in positing a hierarchy in which males situate themselves beneath God and above women, implying that there is a symbolic (and sometimes literal) continuum between God's Rule over humans and male rule over women'. A. Barlas, "Believing Women" in Islam: Unreading Patriarchal Interpretations of the Qur'ān (5th ed.), Austin, Tex: University of Texas Press 2006, 106.

44 Group discussions with Rashid, Abdu and Abdi Bashir, Moyale: June 2010. 
because their frequent sojourning is seen as a neglect of the masculine duty to protect and care for the family. ${ }^{45}$

\section{Conclusion}

The construction of Tablīghi masculinity is an ambivalent mix of entrenchment of some aspects of hegemonic masculinities and, on the other hand, an innovative and selective interpretation of religious texts and practices that reconfigure gender relations and empower ordinary men in society to achieve religious piety and self-esteem through mobility practices. Its innovative aspect lies in its strengthening of hegemonic masculinity through patriarchal power relations while at the same time avoiding some of most visible forms of masculine power in favour of nonpolitical engagement, avoidance of heated debates of all nature, pacifism, 'other-worldliness' and temporal delegation of household headship. The resultant masculinity remains fluid and subject to change and reconstruction through a transnational flow of practices of how to be proper Muslim men. In this manner it appears to bolster the pre-existing Islamic masculinity and the local Cushitic version of being and becoming men, but at the same time proposes and re-enacts new visions of masculinities. Being a new entrant in the religious market of northern Kenya, Tablīghī Jamāat has impacted on everyday practices of ordinary believers. As a network of lay preachers, the movement bonds Tablīghis in every locale in self-sustaining preaching units that constitute an alternative religious platform to the 'ulamā-dominated public sphere. These non-'ulamā men not only embody new practices and mores in their everyday life but also actively impact on the revival of religious practices and worldviews at home.

45 Mandaville, Transnational Muslim Politics, 144. 